\title{
GISimos MCDA LAND SUITABILITY MODEL FOR ECOTOURISM DEVELOPMENT
}

\author{
Fatma AŞILIOĞLU* \\ Kalecik Vocational School, Ankara University, Kalecik, 06870 Ankara, Turkey \\ Received 30 January 2021; accepted 21 May 2021
}

\footnotetext{
Highlights

This article presents a new model, GISimos MCDA, for ecotourism land suitability analysis.

$>$ Contains a comprehensive literature review on GIS-MCDA methods previously used in ecotourism land suitability analysis.

Determines and standardizes the basic criteria for land suitability analysis.

Introduces a classification system to express the levels of land suitability for ecotourism development.
}

\begin{abstract}
Ecotourism development planning is a multi-criteria process that generally requires spatial analysis. GISimos MCDA model developed by this study, was presented for the first time and applied to the Kalecik sub-province of Ankara, Turkey to determine the suitable areas and their suitability levels for ecotourism development. The model is based on the evaluation of sub-factors representing the topography, land cover, climate and sociocultural characteristics of the region, with the combination of GIS and the revised Simos procedure, one of the MCDA techniques. It included a series of processes such as determining the suitability rates and weights of sub-factors, calculating the Ecotourism Suitability Index values, and overlapping them using the WLC method. The resulting values were categorized as highly suitable, moderately suitable, marginally suitable, and not suitable areas. The results of this study and the method developed will be helpful for decision-makers and planners in the study area and similar regions.
\end{abstract}

Keywords: land suitability, multi-criteria decision analysis, MCDA, GISimos, Simos procedure, ecotourism development.

\section{Introduction}

Considering the developments in the global tourism industry, one of the fastest growing types of tourism is nature tourism and its subtype, ecotourism (Cini et al., 2017; Hidrawati et al., 2020; Wondirad et al., 2020). Ecotourism has appeared as a sustainable type of tourism with a minimum negative impact on the environment (CastellanosVerdugo et al., 2016; Mondino \& Beery, 2019; Sriarkarin \& Lee, 2018; Wishitemi et al., 2015). In parallel to the concept of sustainable development, the idea of sustainable tourism came emerged and ecotourism is a suitable choice to achieve it (Asadpourian et al., 2020; D'Souza et al., 2019; Dangi \& Gribb, 2018; Jamaliah \& Powell, 2018).

The development of unplanned or poorly planned ecotourism brings some environmental and sociocultural threats with it (Cobbinah, 2015; Lonn et al., 2018; Tseng et al., 2019). Especially in developing countries, there should be principles for ecotourism on a global and national scale to overcome these threats. Many researchers defined the important factors effective in planning ecotourism development (Arsić et al., 2017; Biglarfadafan et al., 2016). Rather than consuming resources, the focus should be on designing activities that enrich the corresponding area. To achieve this, researchers developed robust methods by assigning values to ecological and social components. One of the significant parts of planning ecotourism is the spatial analysis where multiple factors are analyzed. Thus, many researchers applied Geographic Information Systems (GIS) and Multi-Criteria Decision Analysis (MCDA) to determine ecotourism development areas and rank their suitabilities. The MCDA methods that have been used are Analytic Hierarchy Process (AHP) (Sahani, 2019), Delphi (Bali et al., 2015), Elimination Et Choix Traduisant la Realite (ELECTRE) (Kaptan Ayhan

*Corresponding author. E-mail: fatma.asilioglu@ankara.edu.tr 
et al., 2020), Fuzzy Decision Making Trial and Evaluation Laboratory (FDEMATEL) (Gigović et al., 2016; Jeong \& Ramírez-Gómez, 2018), Fuzzy AHP (Zabihi et al., 2020), Fuzzy ANP (Analytic Network Process) (Aliani et al., 2017), Ordered Weighted Averaging (OWA) (Bunruamkaew \& Murayam, 2011), Technique for Order Performance by Similarity to Ideal Solution (TOPSIS) (Jozi \& Majd, 2015), and WLC (Aliani et al., 2017; Gigović et al., 2016).

This study presents a GISimos MCDA land suitability model to evaluate the land suitability of the Kalecik subprovince of Ankara, Turkey for ecotourism development. The basis of the model is the evaluation of spatial suitability levels for ecotourism development using 18 sub-factors (Sfs) related to the corresponding region's topography, land cover, climate, and sociocultural main factors (MFs). The set of MFs and Sfs were constructed after examining region-specific properties, expert opinions, and other similar studies. Relative weights of the Sfs were determined using one of the MCDA techniques, the revised Simos procedure (Figueira \& Roy, 2002). Later, in the GIS environment, Sf suitability maps were generated, the Ecotourism Suitability Index (ESI) was computed with the multiplication of weights and suitability rates, and then, resultant ESI values were summed with the WLC method. Finally, with these results, a suitability classification map was generated. Even though the Simos procedure is a widely used MCDA technique, its usage frequency is rather low in environmental studies and no study has been reported in the ecotourism literature. However, specifically its revised version provides an easy, understandable and reliable decision-making process that will be an alternative to other MCDA techniques used in this field, especially AHP, which is the most common method. Thus, this study is rare in terms of GIS integration with the Simos procedure for environmental studies, and the first in the ecotourism literature. The aim is to make a start for integrating the Simos procedure, which has been used successfully in many fields, with GIS and adapting it to ecotourism land suitability analyzes, and to provide a decision support tool outside of the complex and conventional methods. At the same time, the findings of the research will be a guide for planners and decision makers in solving similar problems, efficient distribution of resources and encouraging development based on ecotourism.

\section{Materials and methods}

In the management of tourism resources and planning tourism development, approaches based on quantitative evaluation present reliable functional methods that can be applied to different case studies. In this field, GIS is often preferred because it is a rapid and low-cost tool (Mahdavi \& Niknejad, 2014; Sahani, 2019; Ullah \& Hafiz, 2014). This tool also makes it possible to process many spatial data related to inaccessible regions and utilizes remote sensing information. With these advantages, it can generate maps illustrating the ecotourism potential of a region (Jhariya et al., 2016). Integrated use of GIS tools and MCDA is an established method in many fields, such as resource management, environmental planning, urban and regional planning, natural hazard mitigation, water resource management, transportation, tourism development, ecology, agriculture, and forestry (Sahani, 2019). This is because deciding on land suitability is a complex process that requires multi-criteria analysis and incorporating expert opinions from different fields (Aliani et al., 2017; Fung \& Wong, 2007; Gigović et al., 2016). GIS-based MCDA analyzes the problem systematically, makes the best decision using the judgment of experts and comparison of the significances of the criteria (Gigović et al., 2016). The GISimos MCDA spatial model presented in this study is given schematically in Figure 1, and its process steps are explained in the following sections.

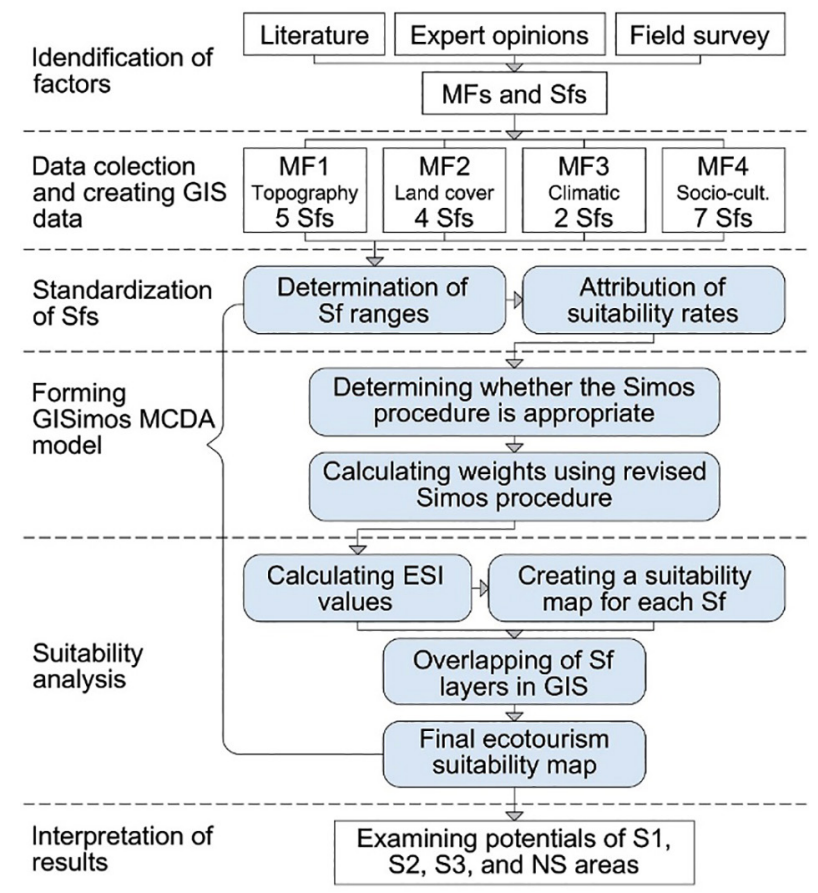

Figure 1. GISimos MCDA model diagram

\subsection{Study area}

The study took place in Turkey's capital, Ankara's subprovince, Kalecik. It is situated between $40^{\circ} 24^{\prime} 27^{\prime \prime}$ and $39^{\circ} 57^{\prime} 8^{\prime \prime}$ north latitude and $33^{\circ} 12^{\prime} 16^{\prime \prime}$ and $33^{\circ} 39^{\prime} 45^{\prime \prime}$ east longitude, covering an area of $1318 \mathrm{~km}^{2}$ (Figure 2). This location is at the intersection of the roads for three major cities, Ankara, Çankırı, and Kırıkkale and is a transition between the Internal Anatolia and the Black Sea Region. It has 57 different districts. The Kizılırmak River is the longest river in Turkey among rivers where both their source and discharge are in Turkey, and the Kalecik region is in the fertile soils of the Middle Kizılırmak Basin. Its altitude is $580-1997 \mathrm{~m}$ above sea-level and its highest point is on the Idris Mountain. The local people's earnings come from 


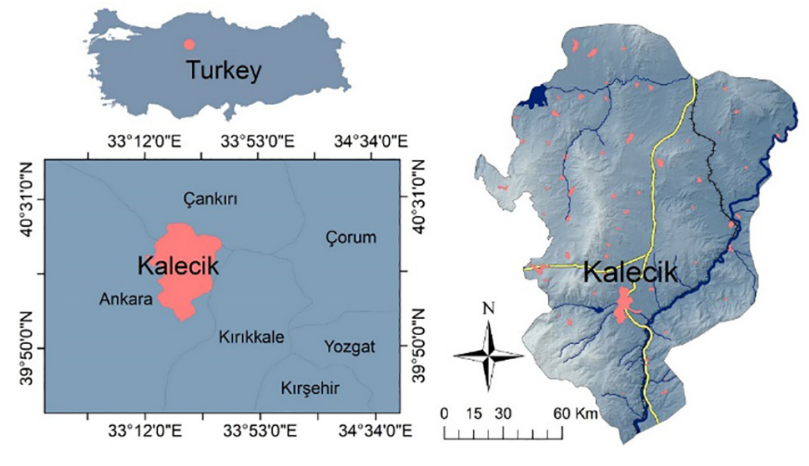

Figure 2. Location of the study area

agriculture, livestock, and other commercial activities. Vitis vinifera L. cv. Kalecik Karası a globally acknowledged plant for red wine production, is a highly economically valuable agricultural product and is also featured as a cultural asset. The region is also rich in tangible and intangible cultural heritage. But, insufficient job opportunities and social activity options result in migration to other places. Especially the young people have abandoned the sub-province.

Several things are necessary to develop ecotourism such as natural beauties, sparse urbanization, traditional culture, unique agricultural methods, traditional local communities, tangible and intangible cultural heritage, rare valuables, and accessibility. Despite Kalecik has most of these characteristics, it did not reach an appropriate tourism level worthy of its characteristics. Planning the development of ecotourism in this region and increasing the awareness of local people and institutions of these values's significance will positively affect its economic development and increase its recognition. Moreover, it will be an important ecotourism destination for the people in the surrounding regions.

\subsection{Identification of factors}

This study aims to put forward an MCDA supported spatial analysis model that will be a foundation for planning ecotourism development in the Kalecik sub-province of Ankara, Turkey. For this reason, the opinions of nine different experts were obtained from the landscape planning, tourism planning, agricultural development, natural resource management, and cultural landscape fields. Additionally, previous similar studies' methods and criteria were examined. Moreover, the natural, cultural, sociologi$\mathrm{cal}$, and economical characteristics of the study area were comprehensively investigated. Finally, a dataset for four MF (topography, MF1; land cover, MF2; climate, MF3; sociocultural, MF4) and their $18 \mathrm{Sf}$ was created to determine the suitable areas for ecotourism. Table 1 illustrates the similar criteria used from various case studies.

\subsection{Data collections and creating GIS data}

The data used in this study were obtained from public institutions, literature, computer programs offering satellite images, open-content websites, and on-site monitoring in different formats. The data entry, digitalization, transformation, classification, and analysis processes were done using the ArcGIS 10.6.1 software tools. The dataset of the study is given in Table 2.

For elevation, slope, Topographic Roughness Index (TRI), visibility, and aspect, the 30-meter spatial resolution DEM of ASTER was used. The visibility map was constructed with 16 reference points, comprised of five of the highest hills overlooking the landscape, the Kalecik Castle, six district centers including one subprovince center, highway entries from three neighboring cities, and one point for the intersection of these three roads. Soil and geology maps were reclassified from the relevant data, The Normalized Difference Vegetation Index (NDVI) map was created with $30 \mathrm{~m}$ spatial resolution Landsat 8 imagery, and the surface water map was drawn in Google Earth Pro 7.3.3 as a KML and converted to an ESRI shapefile. NDVI illustrates the natural landscape's very significant component, vegetation, and is directly proportional to soil fertility. For temperature and precipitation maps, the 5-year average values between 2014-2018 of 9 meteorology stations were used, and the spatial distribution was made by the Inverse Distance Weighting (IDW) interpolation method. A land use map was reclassified from vector data, and road and railway maps were obtained via OpenStreetMap (OSM). For the settlement data, 57 district residential areas were drawn on Google Earth Pro 7.3.3, which then was updated with their impact areas calculated after field studies, and this generated KML file was converted into an ESRI shapefile. Ninety cultural assets in the study area were included in the cultural value map. Some of these were historical buildings registered to the inventory, settlements, fossil beds, and ruins. In addition, further relevant points were inserted, which were determined after field studies, observations, and interviews, and their locations were obtained via a GPS device. These were natural formations such as mountains and plateaus that attract visitors, extraordinary agricultural production areas and facilities, vineyards, vineyard houses, wineries, symbolized statues, and some private contemporary structures. The negative factors in the study area were unwanted facilities in the auditory and visual sense. There were 18 of them, composed of industrial facilities, sand and stone quarries, floodplains, landslide areas, solar energy panel facilities, wastewater treatment plants, solid waste landfill areas, and HPP related constructions. Their coordinates were specified with field studies and the negative factors map was generated. For the population density map, 2019 data of the address-based population register system was used. The built-up areas in the seven districts of the sub-province center are attached to each other. This region is where the economic activities take place and governmental and education facilities, food and beverage services, social facilities, public transportation, and accommodation 


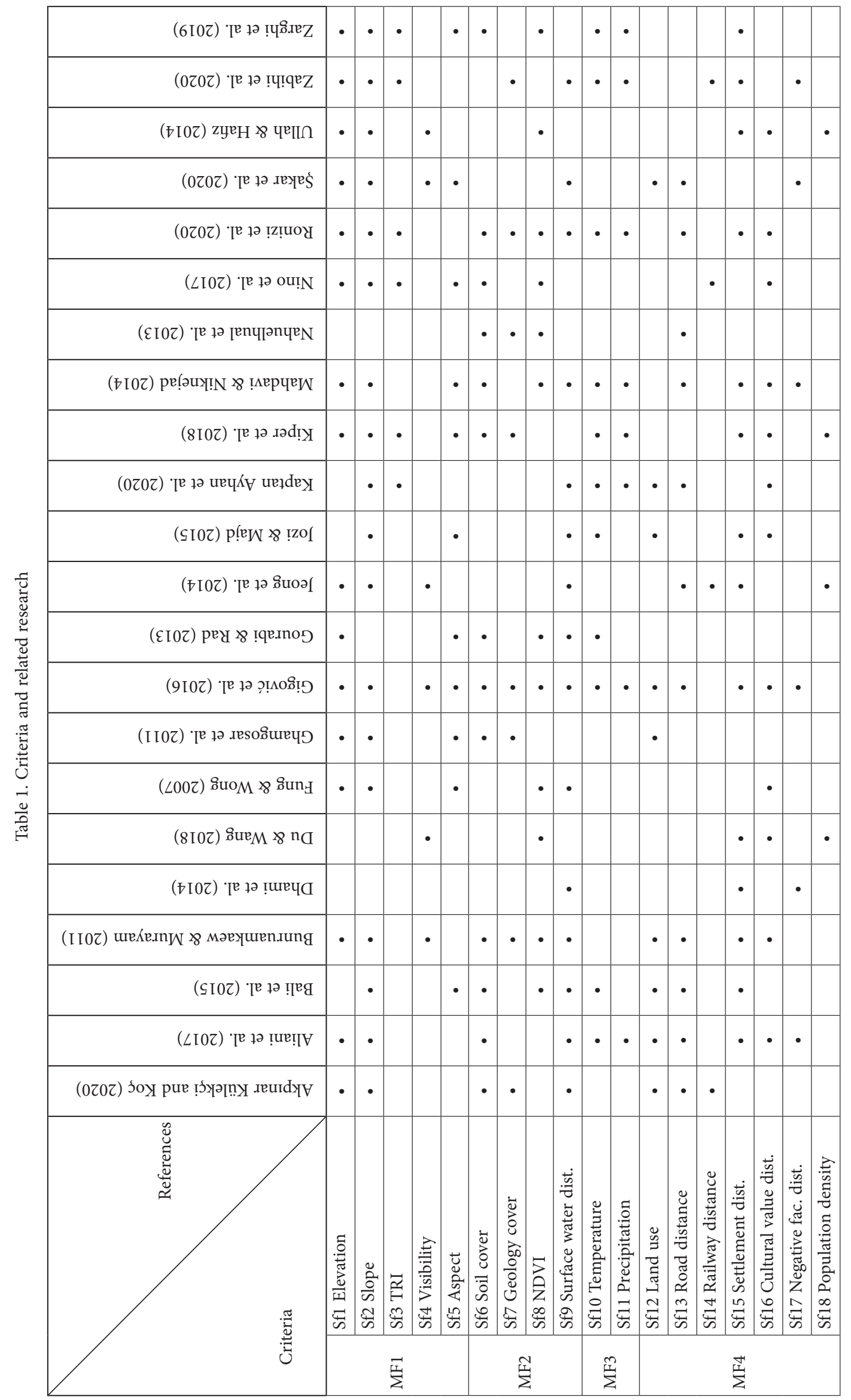


Table 2. Data, processes and sources

\begin{tabular}{|c|c|c|c|c|c|}
\hline MFs & Sfs & Data & $\begin{array}{c}\text { Scale } \\
\text { Resolution }\end{array}$ & Process & Source \\
\hline \multirow{5}{*}{$\begin{array}{l}\text { MF1 } \\
\text { Topography }\end{array}$} & Sf1 Elevation & \multirow{5}{*}{$\begin{array}{l}\text { ASTER } \\
\text { DEM }\end{array}$} & \multirow{5}{*}{$30 \mathrm{~m}$} & \multirow{5}{*}{$\begin{array}{l}\text { Georeferencing Surface } \\
\text { Analysis }\end{array}$} & \multirow{5}{*}{ U.S. Geological Survey (USGS) } \\
\hline & Sf2 Slope & & & & \\
\hline & Sf3 TRI & & & & \\
\hline & Sf4 Visibility & & & & \\
\hline & Sf5 Aspect & & & & \\
\hline \multirow{4}{*}{$\begin{array}{l}\text { MF2 } \\
\text { Land cover }\end{array}$} & Sf6 Soil & $\begin{array}{l}\text { Soil map of } \\
\text { Turkey }\end{array}$ & $1: 25,000$ & Reclassify & $\begin{array}{l}\text { Republic of Turkey Ministry of Agriculture } \\
\text { and Foresty, Soil Fertilizer and Water } \\
\text { Resouces Central Research Institute }\end{array}$ \\
\hline & $\begin{array}{l}\text { Sf7 Geology } \\
\text { cover }\end{array}$ & $\begin{array}{l}\text { Geology map } \\
\text { of Turkey }\end{array}$ & $1: 100,000$ & Reclassify & $\begin{array}{l}\text { General Directorate of Mineral Research } \\
\text { and Exploration }\end{array}$ \\
\hline & Sf8 NDVI & $\begin{array}{l}\text { Landsat } 8 \\
\text { imagery }\end{array}$ & $30 \mathrm{~m}$ & $\begin{array}{l}\text { Georeferencing Surface } \\
\text { Analysis }\end{array}$ & U.S. Geological Survey (USGS) \\
\hline & $\begin{array}{l}\text { Sf9 Distance } \\
\text { from surface } \\
\text { waters }\end{array}$ & $\begin{array}{l}\text { Geographic } \\
\text { data in KML } \\
\text { format }\end{array}$ & $1: 50,000$ & $\begin{array}{l}\text { Conversion from KML } \\
\text { to ESRI shapefile / } \\
\text { Euclidean distance }\end{array}$ & Google Earth Pro 7.3.3 \\
\hline \multirow{2}{*}{$\begin{array}{l}\text { MF3 } \\
\text { Climatic }\end{array}$} & $\begin{array}{l}\text { Sf10 } \\
\text { Temperature }\end{array}$ & \multirow{2}{*}{$\begin{array}{l}\text { Climatic } \\
\text { data / } 5 \text { years } \\
\text { average }\end{array}$} & \multirow{2}{*}{$1: 50,000$} & \multirow{2}{*}{$\begin{array}{l}\text { Georeferencing by IDW } \\
\text { interpolation method }\end{array}$} & \multirow{2}{*}{$\begin{array}{l}\text { Republic of Turkey Ministry of Agriculture } \\
\text { and Foresty, Meteorological Service }\end{array}$} \\
\hline & $\begin{array}{l}\text { Sf11 } \\
\text { Precipitation }\end{array}$ & & & & \\
\hline \multirow[t]{7}{*}{$\begin{array}{l}\text { MF4 } \\
\text { Socio- } \\
\text { cultural }\end{array}$} & Sf12 Land use & $\begin{array}{l}\text { Soil map of } \\
\text { Turkey }\end{array}$ & $1: 25,000$ & Reclassify & $\begin{array}{l}\text { Republic of Turkey Ministry of Agriculture } \\
\text { and Foresty, Soil Fertilizer and Water } \\
\text { Resouces Central Research Institute }\end{array}$ \\
\hline & $\begin{array}{l}\text { Sf13 Distance } \\
\text { from roads }\end{array}$ & \multirow{2}{*}{$\begin{array}{l}\text { Geographic } \\
\text { data in ESRI } \\
\text { shapefile }\end{array}$} & \multirow{2}{*}{$1: 50,000$} & \multirow{2}{*}{ Euclidean distance } & \multirow{2}{*}{ OpenStreetMap } \\
\hline & $\begin{array}{l}\text { Sf14 Distance } \\
\text { from railway }\end{array}$ & & & & \\
\hline & $\begin{array}{l}\text { Sf15 Distance } \\
\text { from settlements }\end{array}$ & $\begin{array}{l}\text { Geographic } \\
\text { data in KML } \\
\text { format }\end{array}$ & $1: 25,000$ & $\begin{array}{l}\text { Conversion from KML } \\
\text { to ESRI shapefile / } \\
\text { Euclidean distance }\end{array}$ & Google Earth Pro 7.3.3 \\
\hline & $\begin{array}{l}\text { SF16 Distance } \\
\text { from cultural } \\
\text { values }\end{array}$ & $\begin{array}{l}\text { Cultural } \\
\text { property } \\
\text { inventory, } \\
\text { field survey } \\
\text { with GPS }\end{array}$ & $1: 50,000$ & Euclidean distance & $\begin{array}{l}\text { Republic of Turkey Ministry of Culture } \\
\text { and Tourism, Ministry of Environment and } \\
\text { Urbanisation, General Directorate of Land } \\
\text { Registry and Cadastre, Çağlar (2008); Çınar } \\
\text { (2020); Güleç (1990); Yeşil (2019) and on- } \\
\text { site monitoring }\end{array}$ \\
\hline & $\begin{array}{l}\text { Sf17 Distance } \\
\text { from negative } \\
\text { factors }\end{array}$ & $\begin{array}{l}\text { Field survey } \\
\text { with GPS }\end{array}$ & $1: 50,000$ & Euclidean distance & On-site monitoring \\
\hline & $\begin{array}{l}\text { Sf18 Population } \\
\text { density }\end{array}$ & $\begin{array}{l}\text { Population } \\
\text { statistics }\end{array}$ & $1: 50,000$ & Density analysis & Turkish Statistical Institute (2019) \\
\hline
\end{tabular}

facilities are situated. For this reason, its impact area is larger than the other built-up areas' impact area. Considering this impact area difference, $2000 \mathrm{~m}$ of buffer was generated for the sub-province center in the maps, but only $500 \mathrm{~m}$ of buffer was applied for the rest. This was the revision method to calculate and map the population density.

\subsection{Standardization of Sfs}

After the criteria selection, the values and ranges were assigned to all Sfs in accordance with the study area and the purpose of the study. The dataset comprises quantitative and qualitative data in various formats, as in other similar studies. As a pre-requisite for MCDA, all values and ranges should be in comparable units to each other and consequently, they needed to be standardized. This standardization process is mandatory in multi-criteria analysis within the GIS environment. Hence, the ecotourism suitability scale was constructed with a 1-to-5 rating scale according to the literature and expert opinions. The scale includes very low (1), low (2), moderate (3), high (4), and very high (5) suitability. The value and value ranges taking the same suitability rate for every Sf were combined digitally and spatially. 


\subsection{GISimos MCDA land suitability model}

As is the case for many sub-fields of environmental planning, the determination of the suitable areas for ecotourism requires correct comparison and evaluation of many factors. In this process, MCDA techniques are reliable tools for decision-makers and the Simos procedure, developed by Jean Simos in 1990, is one of them. This technique makes it possible to rank a set of criteria hierarchically and to assign numerical values when required. In the literature, researchers frequently use this technique to present their preferences and compile expert opinions. The procedure was either used by itself (Alsulaihi, 2017; Marzouk et al., 2014) or with other MCDA techniques, such as ELECTRE (de Sousa Pereira \& Morais, 2020; Merad et al., 2013), Fuzzy AHP (Ribas \& da Silva Rocha, 2015), Preference Ranking Organization Method for Enrichment Evaluation (PROMETHEE) (Govindan et al., 2017), Simple Multi Attribute Rating Technique Exploiting Rank (SMARTER) (Fontana et al., 2011), TOPSIS (Balaji \& Senthil Kumar, 2018), and Closed Procedures near Reference Situations (ZAPROS, in Russian) (Górecka, 2016). But there is no tourism or recreation themed study among them. However, the Simos procedure, especially its revised version by Figueira and Roy (2002), can be quite successful in environmental management fields, as it is in other

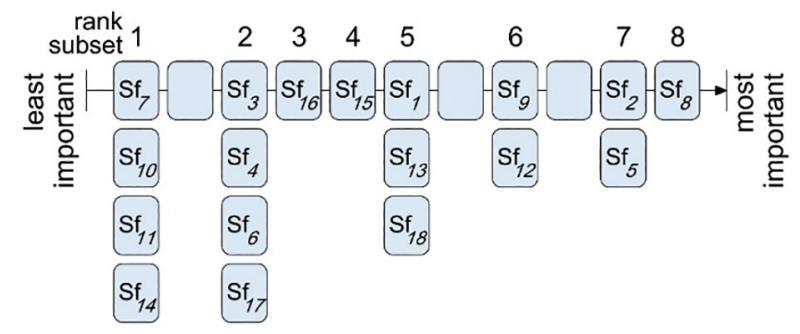

Figure 3. The card-playing method of Simos, adapted from Shanian et al. (2008) fields, and it can be an alternative or complementary to other available methods. AHP is the most used MCDA method in land suitability analysis for ecotourism. The methods of 14 of the 22 studies given in Table 1 are based on AHP. Kahneman (2021) included a general critique of the method and the views of the author in one of his study. Most authors are of the opinion that AHP is not a useful method for setting clear priorities, but rather fragile, complex, and prone to error. In addition, there are researchers who think that the pairwise comparison, which requires excessive repetition of correlations, gives flawed results (Karthikeyan et al., 2016). Often experts have difficulty mastering and consistently maintaining ratings $1-9$. Especially when the number of criteria is high, pairwise comparison tables become very complex and the reliability of the result becomes doubtful. Despite this, compared to other methods, AHP is perceived as a method that is easy to understand and learn, mathematically simple, and gives the decision maker the feeling that it can easily solve complex problems. However, the Simos procedure offers an easier, more understandable and reliable decision-making process even in analyzes where the number of criteria is high to achieve the targeted result with other methods and AHP. Since it is designed as a card-playing, it is possible for the expert to understand and manage the process well. For these reasons, it has the potential to be a useful and powerful MCDA option for spatial analysis of ecotourism development.

Simos procedure is a card-playing method (Figure 3). Every expert took a deck of cards with Sf names written on them and ordered them from the least to most important for the determination of land suitability for ecotourism development. To stress the difference between two consecutive Sfs, white cards were put between them in a number proportional to the difference between them. If the Sfs had the same importance, experts grouped them under the same subset. Instead of sharing the opinions of all experts, an example obtained from their arithmetic

Table 3. Calculation of Sf weights with original Simos procedure

\begin{tabular}{|l|c|c|c|c|c|}
\hline \multicolumn{1}{|c|}{ Subsets of Sf } & $\begin{array}{c}\text { Number } \\
\text { of cards }\end{array}$ & Positions & $\begin{array}{c}\text { Non-normalized } \\
\text { weights }\end{array}$ & $\begin{array}{c}\text { Normalized } \\
\text { weights }\end{array}$ & Total weights \\
\hline Sf7, Sf10, Sf11, Sf14 & 4 & $1,2,3,4$ & $(1+2+3+4) / 4=2.50$ & 1.30 & $4 \times 1.30=5.20$ \\
\hline White & 1 & $(5)$ & - & - & $4 \times 3.89=15.56$ \\
\hline Sf3, Sf4, Sf6, Sf17 & 4 & $6,7,8,9$ & $(6+7+8+9) / 4=7.50$ & 3.89 & $1 \times 5.18=5.18$ \\
\hline Sf16 & 1 & 10 & 10.00 & 5.18 & $1 \times 5.70=5.70$ \\
\hline Sf15 & 1 & 11 & 11.00 & 5.70 & $3 \times 6.74=20.22$ \\
\hline Sf1, Sf13, Sf18 & 3 & $12,13,14$ & $(12+13+14) / 3=13.00$ & 6.74 & - \\
\hline White & 1 & $(15)$ & - & - & $2 \times 8.55=17.10$ \\
\hline Sf9, Sf12 & 2 & 16,17 & $(16+17) / 2=16.50$ & 8.55 & - \\
\hline White & 1 & $(18)$ & - & - & $2 \times 10.10=20.20$ \\
\hline Sf2, Sf5 & 2 & 19,20 & $(19+20) / 2=19.50$ & 10.10 & $1 \times 10.88=10.88$ \\
\hline Sf8 & 1 & 21 & 21.00 & 10.88 & 100 \\
\hline Sum & 21 & $193^{\star}$ & - & & \\
\hline
\end{tabular}


mean is given in Table 3 . It also shows the weights obtained with the original Simos procedure.

After this step, the revised Simos procedure developed by Figueira and Roy (2002) starts and first the $z$ value, which is the ratio of the weight of the most important Sf and the least important Sf, is calculated from Table 3 with the Eq. (1):

$$
z=\frac{\left(\sum_{i=0}^{q-1}(T-i)\right) p}{\left(\sum_{i=0}^{p-1}(1+i)\right) q},
$$

where $T$ is the total number of cards, $q$ is the Sf number in the most important subset, and $\mathrm{p}$ is the Sf number in the least important subset. The computed $z$ value is 8.4 . The second step is the calculation of non-normalized weights $k(r)$. For this, firstly, $u$, the difference between weights, was computed with the Eqs (2), (3) and (4).

$$
\left\{\begin{aligned}
& e_{r}=e_{r}^{\prime}+1 \forall r=1, \ldots, \bar{n}-1 ; \\
& e=\sum_{r=1}^{\bar{n}-1} e_{r} \\
& u=\frac{z-1}{e},
\end{aligned}\right.
$$

where $e_{r}^{\prime}$ is the number of white cards between the ranks $r$ and $r+1$. As can be seen in Table 4, the calculated $e$ value is 10 and $u$ is 0.74 . We obtained the Eq. (5) with $e_{0}=0$.

$$
k(r)=1+u\left(e_{0}+\ldots+e_{r-1}\right),
$$

where $k(r)$ is non-normalized weights. The third step is the calculation of the normalized weights $k_{i}^{*}$ with the Eqs (6) and (7) (Table 4).

$$
\left\{\begin{array}{l}
K^{\prime}=\sum_{i-1}^{n} k_{i}^{\prime} ; \\
k_{i}^{*}=\frac{100}{K^{\prime}} k_{i}^{\prime},
\end{array}\right.
$$

where $k_{i}^{\prime}$ is weight of the Sf, its non-normalized expression $k_{i}^{\prime}=k(r)$.

Comparing the maximum and minimum weights obtained in Table 4 with the characteristics of the study area can be quite beneficial to question the results' proximity to reality. The least important Sfs with a $1.40 \%$ ratio were geology cover Sf7, temperature Sf10, precipitation Sf11, and distance from railway Sf14. The major part of the study area has limestone, melange, sandstone, mudstone, conglomerate, and alluviums. There is no role for these in ecotourism in the study area, other than agricultural fertility and vegetation cover. As they have already been considered in soil, land use and NDVI, low weight was given to geological cover. The range of temperature and precipitation in the study area was too little to affect ecotourism development in the region. The distance from the railway is among the least important as it only transports loads, not people. On the other hand, the most important Sf with $8.40 \%$ is Sf8 NDVI. It is an important indicator of ecotourism. The forested area is suitable for many activities and the agricultural area is also important in this region, both of which NDVI reflects.

\subsection{Suitability analysis}

Suitability analysis was done first by multiplication of the $k_{i}^{\prime}$ given in the GISimos MCDA land suitability model section, and $s_{i}$ given in the Standardization of Sfs section; and then, projecting of the resulted ESI values to maps. ESI is formulated as in the Eq. (8):

$$
E S I=s_{i} \times k_{i}^{\prime} \quad \forall s_{i}=1, \ldots, 5 .
$$

Theoretically, ESI takes the least value for $s_{i}=1$ and $k_{i}^{\prime}=0$ and the highest value for $s_{i}=5$ and $k_{i}^{\prime}=100$. Table 5 lists the ESI value for all Sfs, and Figure 4 shows the suitability maps according to each Sf's ESI values.

The WLC method was used to overlap GIS layers for every Sf and sum them. The most important advantage of the method is that in the studies related to planning, such as in this study, it can simultaneously evaluate the properties, such as under the titles of topography, land cover, climate, and sociocultural factors. The WLC gives quick and reliable results while holistically expressing the data obtained from MCDA methods in a GIS environment (Aliani et al., 2017; Bunruamkaew \& Murayam, 2011; Dashti et al., 2013). The WLC obtained an ESI for each $30 \times 30 \mathrm{~m}$ size raster by

Table 4. Calculation of Sf weights with revised Simos procedure

\begin{tabular}{|c|c|c|c|c|c|}
\hline Rank $r$ & Sf in the rank $r$ & Number of white cards $e_{r}^{\prime}$ & $e_{r}$ & Non-normalized weights $k(r)$ & Normalized weights $k_{i}^{\prime}$ \\
\hline 1 & Sf7, Sf10, Sf11, Sf14 & 1 & 2 & $1.00 \times 4=4.00$ & $1.40 \times 4=5.60$ \\
\hline 2 & Sf3, Sf4, Sf6, Sf17 & 0 & 1 & $2.48 \times 4=9.92$ & $3.48 \times 4=13.92$ \\
\hline 3 & Sf16 & 0 & 1 & $3.22 \times 1=3.22$ & $4.52 \times 1=4.52$ \\
\hline 4 & Sf15 & 0 & 1 & $3.96 \times 1=3.96$ & $5.56 \times 1=5.56$ \\
\hline 5 & Sf1, Sf13, Sf18 & 1 & 2 & $4.70 \times 3=14.10$ & $6.59 \times 3=19.77$ \\
\hline 6 & Sf9, Sf12 & 1 & 1 & $6.18 \times 2=12.36$ & $8.67 \times 2=17.34$ \\
\hline 7 & Sf2, Sf5 & 0 & - & $7.66 \times 2=15.32$ & $10.75 \times 2=21.50$ \\
\hline 8 & Sf8 & - & 10 & $8.40 \times 1=8.40$ & $11.78 \times 1=11.78$ \\
\hline Sum & 18 & 3 & & 71.28 & 100 \\
\hline
\end{tabular}


Table 5. ESI values for Sfs

\begin{tabular}{|c|c|c|c|c|c|}
\hline \multicolumn{3}{|c|}{ MF1 Topography } & \multicolumn{3}{|c|}{ MF3 Climate } \\
\hline Sfs & & ESI & Sfs & & ESI \\
\hline \multirow{3}{*}{$\begin{array}{l}\text { Sf1 } \\
\text { Elevation (m) }\end{array}$} & $580-880$ & 32.95 & \multirow{3}{*}{$\begin{array}{l}\text { Sf10 } \\
\text { Temperature } \\
\left({ }^{\circ} \mathrm{C}\right)\end{array}$} & $11.80-13.40$ & 7.00 \\
\hline & $880-1170$ & 26.36 & & $10.00-11.80$ & 4.20 \\
\hline & 1170-1997 & 19.17 & & $8.20-10.00$ & 1.40 \\
\hline \multirow{5}{*}{$\begin{array}{l}\text { Sf2 } \\
\text { Slope (\%) }\end{array}$} & $0-6$ & 53.75 & \multirow{3}{*}{$\begin{array}{l}\text { Sf11 } \\
\text { Precipitation } \\
\text { (mm/year) }\end{array}$} & $375.00-419.10$ & 7.00 \\
\hline & $6-12$ & 43.00 & & $330.00-375.00$ & 5.60 \\
\hline & $12-20$ & 33.25 & & $291.05-330.00$ & 4.20 \\
\hline & $20-30$ & 21.50 & & MF4 Sociocultural & \\
\hline & $30<$ & 10.75 & Sfs & & ESI \\
\hline \multirow{5}{*}{$\begin{array}{l}\text { Sf3 } \\
\text { TRI }\end{array}$} & $<0.26$ & 17.40 & \multirow{6}{*}{$\begin{array}{l}\text { Sf12 } \\
\text { Land use }\end{array}$} & Vineyard, orchard & 43.35 \\
\hline & $0.26-0.39$ & 13.92 & & Meadow & 34.68 \\
\hline & $0.39-0.47$ & 10.44 & & Dryland agriculture & 26.01 \\
\hline & $0.47-0.56$ & 6.96 & & Irrigated agriculture & 17.34 \\
\hline & $0.56-0.86$ & 3.48 & & Shrub land, water- & 867 \\
\hline \multirow{2}{*}{$\begin{array}{l}\text { Sf4 } \\
\text { Visibility }\end{array}$} & Visible & 17.40 & & industry-settlement & 0.01 \\
\hline & Not visible & 10.44 & \multirow{5}{*}{$\begin{array}{l}\text { Sf13 } \\
\text { Distance from roads } \\
(\mathrm{m})\end{array}$} & $<1000$ & 32.95 \\
\hline \multirow{5}{*}{$\begin{array}{l}\text { Sf5 } \\
\text { Aspect }\end{array}$} & South & 53.75 & & $1000-2000$ & 26.36 \\
\hline & South, southwest & 43.00 & & $2000-3000$ & 17.77 \\
\hline & East, west & 32.25 & & $3000-4000$ & 13.18 \\
\hline & Northeast, northwest & 21.50 & & $4000<$ & 6.59 \\
\hline & North & 10.75 & \multirow{5}{*}{$\begin{array}{l}\text { Sf14 } \\
\text { Distance from } \\
\text { railway (m) }\end{array}$} & $2000<$ & 7.00 \\
\hline & MF2 Land cover & & & $1500-2000$ & 5.60 \\
\hline Sfs & & ESI & & $1000-1500$ & 4.20 \\
\hline \multirow{5}{*}{$\begin{array}{l}\text { Sf6 } \\
\text { Soil cover }\end{array}$} & Chestnut & 17.40 & & $500-1000$ & 2.80 \\
\hline & Brown forest, reddish & 1202 & & $<500$ & 1.40 \\
\hline & brown, alluvial & 15.92 & \multirow{5}{*}{$\begin{array}{l}\text { Sf15 } \\
\text { Distance from } \\
\text { Settlements }(\mathrm{m})\end{array}$} & $<1000$ & 27.80 \\
\hline & Brown & 10.44 & & $1000-2000$ & 22.24 \\
\hline & Colluvial & 6.96 & & 2000-3000 & 16.68 \\
\hline \multirow{10}{*}{$\begin{array}{l}\text { Sf7 } \\
\text { Geology cover }\end{array}$} & Conglomerate-sandsto- & 700 & & $3000-4000$ & 11.12 \\
\hline & ne-mudstone, alluvium & 1.00 & & $4000<$ & 5.56 \\
\hline & Melange, sandstone- & & \multirow{5}{*}{$\begin{array}{l}\text { Sf16 } \\
\text { Distance from } \\
\text { Cultural values (m) }\end{array}$} & $<1000$ & 22.60 \\
\hline & mudstone-limestone, & 5.60 & & $1000-2000$ & 18.08 \\
\hline & limestone & & & $2000-3000$ & 13.56 \\
\hline & Volcanite-sediment & 4.20 & & $3000-4000$ & 9.04 \\
\hline & \multirow{2}{*}{$\begin{array}{l}\text { Olistostrome, } \\
\text { metaolistostrome }\end{array}$} & \multirow{2}{*}{2.80} & & $4000<$ & 4.52 \\
\hline & & & \multirow{5}{*}{$\begin{array}{l}\text { Sf17 } \\
\text { Distance from } \\
\text { Negative factors (m) }\end{array}$} & $2000<$ & 17.40 \\
\hline & \multirow{2}{*}{$\begin{array}{l}\text { Peridotite, andesite- } \\
\text { basalt-dacite, evaporite }\end{array}$} & 140 & & $1500-2000$ & 13.92 \\
\hline & & 1.40 & & $1000-1500$ & 10.44 \\
\hline \multirow{5}{*}{$\begin{array}{l}\text { Sf8 } \\
\text { NDVI }\end{array}$} & Very high $(0.48-0.65)$ & 58.90 & & $500-1000$ & 6.96 \\
\hline & High $(0.32-0.48)$ & 47.12 & & $<500$ & 3.48 \\
\hline & Moderate (0.16-0.32) & 35.34 & \multirow{3}{*}{$\begin{array}{l}\text { Sf18 } \\
\text { Pop. density } \\
\left(\text { per } \mathrm{km}^{2}\right)\end{array}$} & $100-140$ & 32.95 \\
\hline & Low $(0.00-0.16)$ & 23.56 & & $70-100$ & 26.36 \\
\hline & Very low $(>0.00)$ & 11.78 & & $<70$ & 19.77 \\
\hline & $<700$ & 43.35 & & & \\
\hline Sf9 & $700-1400$ & 34.68 & & & \\
\hline $\begin{array}{l}\text { Distance from } \\
\text { surface waters }\end{array}$ & $1400-2100$ & 26.01 & & & \\
\hline & $2100-2800$ & 17.34 & & & \\
\hline & $2800<$ & 8.67 & & & \\
\hline
\end{tabular}



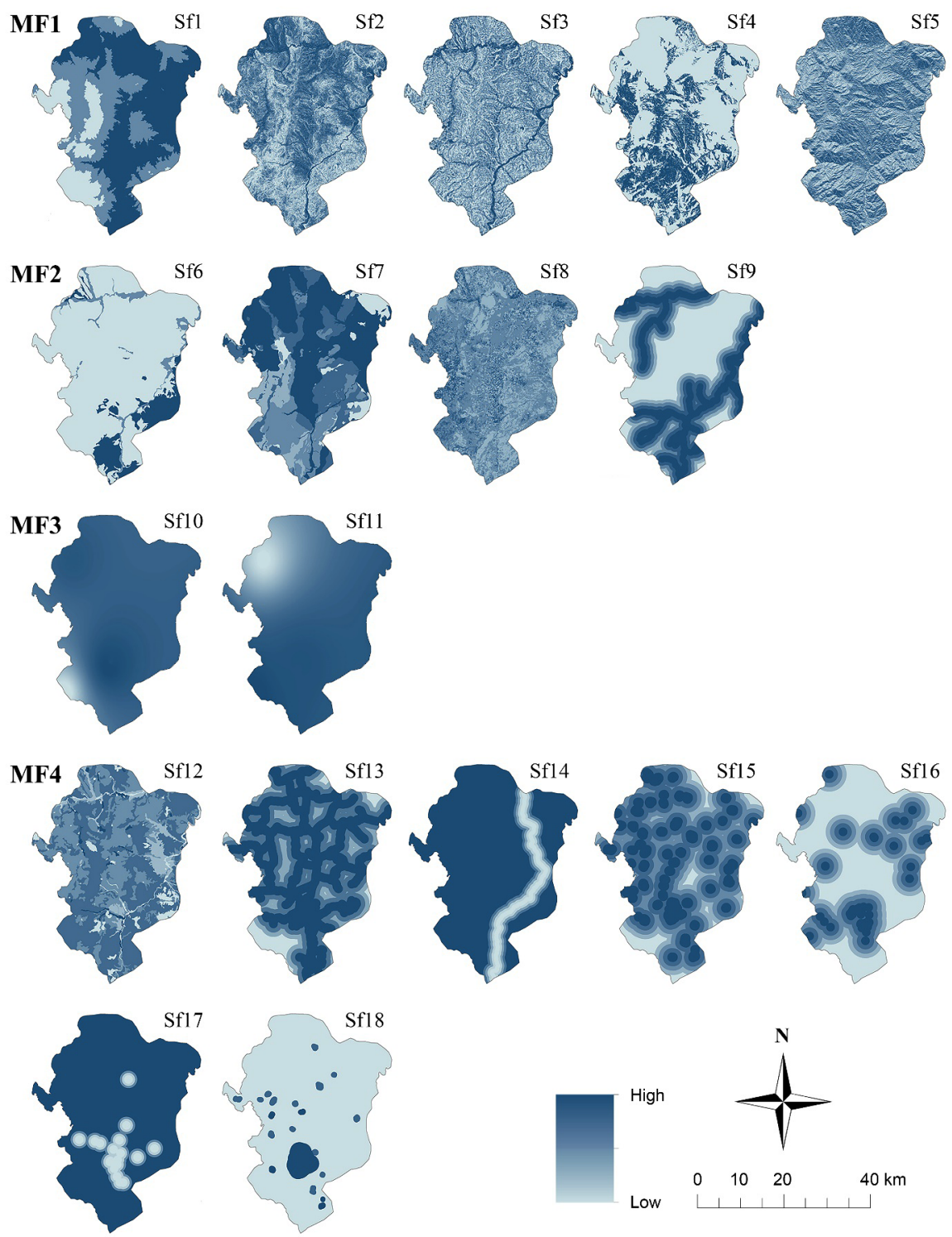

Figure 4. Suitability analysis according to ESI values

multiplying si and k'i for all 18 Sfs and summed all layers' ESI in the GIS environment. After that, the next step was grouping different ESI values and determining the varying suitability levels of the study area for ecotourism development. In the final map, using ArcGIS 10.6.1 ESRI software's "natural breaks method", the range of between the highest and lowest ESI sums was broken into 4 different parts. This method was designed to separate the range in the best way according to its values' statistical properties. It applies an iterative procedure that minimizes intra-range differences and maximizes inter-range ones. Its use is widespread in the classification and mapping of geographical data (Yang et al., 2016). As a result, based on Food and Agriculture Organization's land evaluation scale's land suitability class levels, four levels were determined as S1 (highly suitable), S2 (moderately suitable), S3 (marginally suitable), and NS (not suitable) (Food and Agriculture Organization [FAO], 1976). Figure 5 illustrates the MF maps and the final map. The darker the region in these maps, the more suitable they are for the ecotourism development.

\section{Results and discussions}

With the GISimos MCDA model, four different suitability levels for ecotourism development were determined for the Kalecik sub-province, S1, S2, S3, and NS.

\subsection{Highly suitable areas, $S 1$}

The S1 areas are highly suitable for ecotourism development. They cover $178.88 \mathrm{~km}^{2}$ or $14 \%$ of the entire study area. Overall, they are at $580-880 \mathrm{~m}$ of altitude, rarely at $880-1170 \mathrm{~m}$ of altitude, flat or near-flat with $0-6 \%$ slope, and with low TRI value areas. They are visible in the sub-province center and surroundings, but there are also not visible parts in other regions. They have all aspects except north, northeast, and northwest. Even though a 


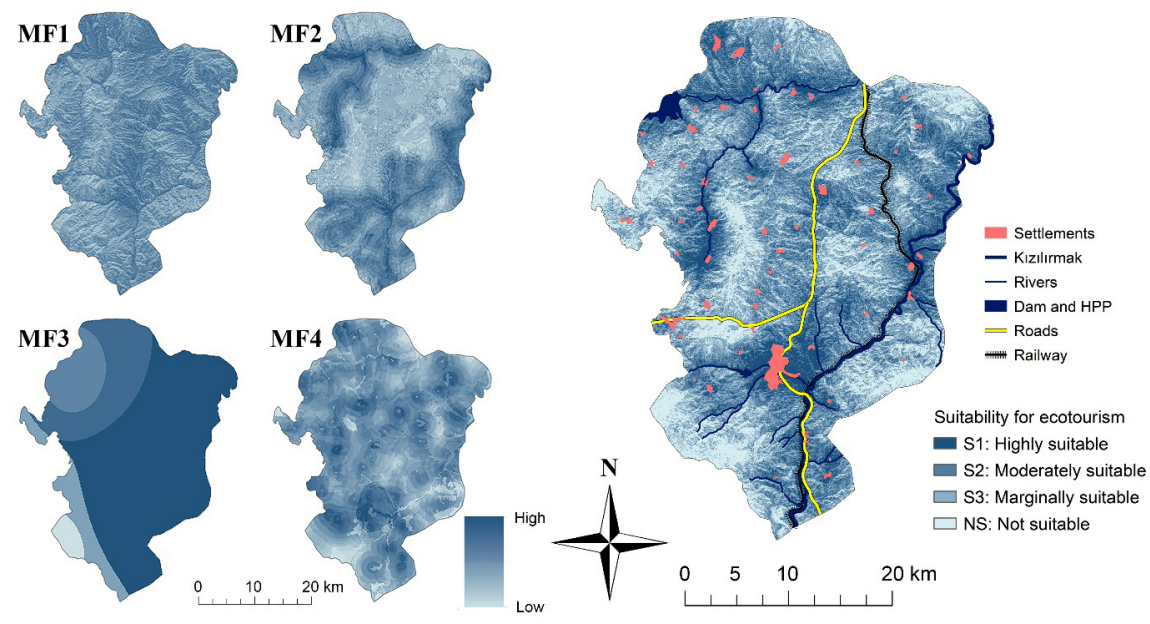

Figure 5. The final ecotourism suitability map

high majority of the Kalecik sub-province is covered with brown soil, these areas are found in alluvial soils stretching through valleys and in all soil classes in the sub-province center. Conglomerate-sandstone-mudstone and alluvium draw attention in the geology cover. High NDVI value areas, valleys of Kizılırmak and other rivers, and their forested and scrub areas are all in S1. When the final map is examined, the impact of rivers on $\mathrm{S} 1$ areas' distribution is clear. Other water bodies in the region, dams, and HPPs are out of these S1 areas. S1 areas' highest and lowest yearly temperature and precipitation averages are close to each other. The lowest temperature average was from the İdris Mountain and surroundings, while the lowest precipitation encompasses the Koyunbaba Dam in the northwest part of the study area. Other than these, the distribution of $\mathrm{S} 1$ areas is independent of temperature or precipitation. The sub-province center, irrigated agriculture areas found in the north and northeast, scattered dryland agriculture areas, vineyards, orchards, and occasional meadows are under this category. The main highways traversing the region through Ankara-Çankırı or Kırıkkale-Çankırı did not affect the distribution because secondary roads envelop the entire region like a cobweb, and consequently, no additional transportation infrastructure is required. There is only a relationship between $\mathrm{S} 1$ areas and main highways surrounding the center of the sub-province. Railways, on the other hand, only serve for load transportation, and the destinations in the region are not actively used. Indeed, the railway is only seen as a source of noise and S1 distribution is far from railway lines. Yet, settlements and their proximities are in S1 areas. Unfortunately, settlements also have the following negative factors: industrial facilities, sand and stone quarries, solar energy panel facilities, wastewater treatment plants, solid waste landfill facilities, and some structures related to HPPs are situated near the sub-province center. However, as the other positive factor effects are much stronger, the negative factors are mostly seen in S1 areas. Places with high population densities are in $\mathrm{S} 1$ areas, first with the sub-province center, then Hasayaz, Değirmenkaya and Karahöyük villages in the west, the Gökdere and Samanlık villages in the south, the Alibeyli village in the east, and the Sat1lar village in the north.

These areas are highly suitable for soft ecotourism activities. They have alluvial covered valley areas, dryland agriculture areas, vineyards, orchards including fertile regions, forests, and scrubs. For this reason, they are both sensitive to ecotourism development and have high potential. Especially in the parts relatively far from settlements, with some restrictions on the use of natural resources, time-controlled and intensity restricted ecotourism opportunities can be encouraged. These can be education and research related to ecotourism, nature photography, sightseeing, wine degustation trips, harvesting, vintage, and reaching out to local agricultural products. As its slope and TRI is reasonable, bicycling is possible. Especially on the shorelines of Kizılirmak, there are already recreational fishing and amateur water sport activities. As S1 areas cover settlements and near-environments, present or potential infrastructure for ecotourism, transportation, accommodations, shopping, and eating-drinking can be provided easily. They are also suitable for camping and riding, which require infrastructure. Settlements are also rich in tangible and intangible cultural heritage. Firstly, culture tourism aiming to experience the cultural heritage of the local lifestyle is very appropriate in these $S 1$ areas. It is possible to visit historical and archeological sites there. The majority of the local people live in S1 areas. Especially in villages, traditional lifestyles persist, and consequently, local production continues, which make these areas very suitable for people willing to experience traditional life and activities. They have the necessary manpower and young population for the development of ecotourism. These areas can be quite attractive to ecotourists for arranging festivals and agriculture fairs, visiting vineyards, visiting barnyards in local architecture, local product promotion, and organic agriculture products sales points. 


\subsection{Moderately suitable areas, $\mathrm{S} 2$}

The S2 include moderately suitable areas for ecotourism and covers $493.16 \mathrm{~km}^{2}$ or $37 \%$ of the study area. They are mostly around $\mathrm{S} 1$ areas as if outer layer zones, but they can also be seen in the entire region. Generally, they are at 580-1170 $\mathrm{m}$ of altitude and their presence is lower in higher altitude sections of the western part and the İdris Mountain. S2 areas usually have $6-20 \%$ slope, rarely $20-30 \%$ slopes, and the TRI is between 0.39 and 0.47 with moderately undulating topography. In the south, they are in visible regions, whereas in the north they are not in visible parts. Excluding the north, northeast, and northwest, they can be found on all aspects. S2 areas are distributed mostly in brown and reddish-brown soils. Their geological covers are primarily conglomerate-sandstone-mudstone and alluvium, followed by limestone, mélange, and sandstone-mudstone-limestone. Except for bare soil, they are distributed in all middle-level NDVI areas. When the final map is examined, as much as they are in the riverine regions, S2 areas are in other parts, as well. Similarly, they are distributed outside of the İdris Mountain and surroundings where the yearly temperature average is lower. Other than this, the yearly precipitation average does not affect the distribution of S2 areas. The Koyunbaba Dam and surrounding areas receive the lowest amount of precipitation and they are in S2 areas. The meadows and drylands surrounding S1 areas are S2 areas. Their distribution is independent of main roads, secondary roads, or railways because the transportation network in the region is already sufficient. Considering the relationships with the settlements, they are located densely around the S1 areas, which include settlements, but they are also in other places. They encompass some negative factors in the settled areas, and generally, they are distributed in less densely populated areas.

S2 areas are the center of attraction for both hard and soft ecotourism activities. They are like a buffer region between settlements and rural areas. In sensitive areas, controlled and restricted ecotourism is possible, whereas in other places it can be more flexible. Some S2 areas' slope and TRI are suitable for bicycling. They are also appropriate with their middle-level NDVI values for botanical and herbal activities, wildlife and flora observation, nature photography, sightseeing, picnicking, hiking, and trekking activities. River routes, especially the shoreline of Kizilırmak, are very suitable for fishing and amateur water sports. Vast meadows and rare dryland agriculture areas offer hobby farming, harvest, vintage, and access to local agriculture products. Especially the areas near settlements have the potential to develop infrastructure, transportation, accommodations, shopping, and food and beverage services. It is also possible to construct the necessary infrastructure for riding and camping. At the same time, they are near tangible and intangible cultural values. They are relatively less densely populated. For this reason, ecotourism activities requiring fewer local people and manpower should be planned and developed in these areas.

\subsection{Marginally suitable areas, $\mathrm{S} 3$}

The S3 correspond to the areas marginally suitable for ecotourism development and covered $421.33 \mathrm{~km}^{2}$ or $32 \%$ of the entire study area. Generally, they are like a buffer between S2 and NS areas, and sometimes scattered in NS areas. They are distributed in all altitudes, all slopes equal to or greater than $12 \%$, TRI values $>0.47$, and in visible regions in the south and not visible ones in the north. They rarely reside in the south, southeast, or southwest aspects. These areas are covered by brown soil, brown forest soil, and reddish-brown soil and show a distribution independent of geological cover. They are scattered around middle and low NDVI values. Even though they exist in Koyunbaba Dam's surrounding area in the northwest and middle parts of the Kizllirmak Valley in the southeast with S1 and S2 areas, they are generally found in areas far from rivers. In the parts outside of the S1 and S2, their distribution is uncorrelated with temperature or precipitation changes. Usually, they cover dryland agriculture areas and meadows. Similar to the other categories, main road related factors do not affect their distribution. Since the railway is considered a negative factor, a major part of it is in S3 category areas. Other negative factors are generally in S1 and S2 areas as they are nearer to the settlements. They comprise the rural areas between villages with very low population densities.

S3 areas generally have the potential to be developed for hard ecotourism activities. Their sensitivity is low and they provide limited opportunities. In these areas with mostly middle or low-value NDVI, the ground is either covered by vegetation or low-height bushes. Compared to the S1 and S2, they cover higher altitude areas. They can be developed for more rural and natural ecotourism activities as they are distant from infrastructure and local people and mostly related to the local agriculture and livestock activities since they are covered with either dryland or meadows. With its characteristics, they are suitable for botanical and herbal activities, wildlife and flora observation, nature photography, sightseeing, and trekking. They are far from settlements and except for long walking routes, they can only be reached by motor vehicles. As a result, except for a low number of archeological sites, they do not contain a tangible or intangible cultural value. Despite all restrictions, the accommodation units, food and beverage services, shopping malls, and other large structures might be built and benefit the area.

\subsection{Not suitable areas, NS}

The NS include the areas currently not suitable for ecotourism development and covers $224.62 \mathrm{~km}^{2}$, which corresponds to $17 \%$ of the entire region. These areas are generally in the hills and ridges over $1170 \mathrm{~m}$ of altitude, such as the İdris Mountain, in all places with $>20 \%$ slope, undulating topography with very high TRI, and usually not visible or barely visible parts. These areas are mostly on the north, northeast, and northwest faces of the mountains. 
Soil cover is composed of brown and reddish-brown soils. Geology cover contains all types except for volcanite-sedimentary. The NDVI is in general below the middle value in NS areas. These areas are distributed mainly in distant places from rivers, valleys, dams, and HPPs and in high altitudes. They cover the regions with the lowest temperature and precipitation average observed and they are in bare or meadow parts. Excluding a very small part of the Ankara-Çankırı highway in the western region, NS areas are far away from main and secondary roads, railways, settlements, and cultural values. Moreover, some negative factors, such as stone and sand quarries, are in NS areas. In summary, these areas are not preferred as a living place by local people and are only rarely used for agricultural purposes. Despite all negative properties, some hard ecotourism activities might still be realized in these regions after their development.

\section{Conclusions}

Ecotourism is one the fastest growing sectors in many countries (Gigović et al., 2016; Olafsdottir, 2013; The International Ecotourism Society [TIES], 2019) at the same time is an attractive sustainable tourism option. It includes an endeavor to protect the presence of the natural environment and support sustainable development. It aims to minimize the negative environmental impact, support the economic development of the local communities, and find funding for protection and development plans (Aliani et al., 2017). This is the first study to use a GISimos MCDA land suitability model in the determination of land suitability for ecotourism development and used the Kalecik sub-province of Ankara, Turkey as a case study. The integration of GIS skills with the MCDA technique includes intelligence, design, and choice phases (Bunruamkaew \& Murayam, 2011; Malczewski, 1999). There are many studies where this integration was employed to obtain more correct and measurable results (Aliani et al., 2017; Mahdavi et al., 2015). With its first-time application, the model aims to be a decision-making support tool in planning and evaluating the ecotourism potential of a specific region. Its most important advantage is its capability to simultaneously and relatively evaluate many criteria related to the topography, land cover, climate, and sociocultural characteristics and digitize it, making it possible to analyze the data spatially with GIS tools. In order to measure the ecotourism suitability of the region, the unique characteristics of the study area, expert opinions, and literature were examined and $18 \mathrm{Sfs}$ were specified. Each Sf was assigned a 1-to-5 suitability rate. Then, since different criteria were expected to carry different importance, the revised Simos procedure, an MCDA method developed by Jean Simos and later revised by Figueira and Roy (2002), calculated their weights. In order to overlap all Sfs, weights and suitability rates were multiplied and resultant ESI values were summed with the WLC method. Finally, a land suitability class based on FAO's land evaluation was employed. According to the final map, four different suitability levels exist including S1, S2, S3, and NS and covering $14 \%, 37 \%, 32 \%$, and $17 \%$ of the study area, respectively. The GISimos MCDA model successfully revealed areas suitable for ecotourism development and their suitability levels in line with the determined criteria. Without a doubt, every region has unique characteristics, and they might require different measurement methods. In subsection 1.1, the location of the study area at the intersection of three major cities and in the fertile lands of the Kizılırmak Basin is mentioned. The potential of Kalecik in terms of topographic structure, natural beauties, traditional life, agricultural value, tangible and intangible heritage is detailed in subsection 1.3. Despite this potential, it is mentioned that the economy, visibility, recognition and rural development could not be improved due to the lack of proper spatial planning. In subsection 1.2, datasets of 22 studies conducted in completely different regions in different countries in the last 14 years are given. As a result, the research methodology, which is explained step by step and in detail in section 1, has the ability to be used in cities and sub-provinces that are similar to Kalecik, and can be modified according to the purpose and region in different ones.

In addition, some limitations of the methodology can be mentioned. Experts' preferences are limited to the Sfs offered to them and they tend to give priority to those related to their field of expertise (Siskos \& Tsotsolas, 2015). In order to overcome this, Sfs were determined by making a comprehensive literature review, and the experts were encouraged to be objective by explaining the scope of the MCDA clearly. Unstable results are likely to occur if the MCDA procedure is misunderstood or not understood (Papathanasiou, 2021). That's why Simos' card-playing method has been applied to experts face to face. As with most MCDA techniques, there is no consensus on the number of decision makers in the Simos procedure. Increasing or decreasing this number and diversifying areas of expertise may affect the results. Standardization of Sfs differs among researchers. For example, some researchers targeted hard ecotourism and determined that areas far from settlements are more suitable for ecotourism development (Gigović et al., 2016). Some of them targeted soft ecotourism and stated that the areas closest to the settlements are more suitable, especially in rural areas (Aliani et al., 2017; Sahani, 2019; Ullah \& Hafiz, 2014). This study was conducted in a rural area and aimed at soft ecotourism.

The motivations of ecotourists are, in general, to experience less crowded, remote, and wilderness areas; learn about nature, wildlife, natives, and cultures; observe flora and fauna; contribute to the community; and do physical activity. The study area has the potential to meet all these expectations for the people living in neighboring cities. Because this potential was not yet discovered or evaluated properly, the region is not popular, continuously loses people with migrations to other regions, and no funding 
is allocated to protect and nurture natural, traditional, and cultural values. However, ecotourism both provides revenue to local people and increases their quality of life via novel commercial activities (Gigović et al., 2016; Hunt et al., 2015; Strickland-Munro \& Moore, 2013). Even though the study was done in the Kalecik region, it presents a method to determine the ecotourism development areas for other similar areas considering all significant criteria and provides a basis for matching that region with relevant activities. Planners and decision-makers can use this method to allocate resources effectively and manage ecotourism-based development with this spatial and decision-making model.

\section{References}

Akpınar Külekçi, E., \& Koç, A. (2020). Analysis of the areas suitable for ecotourism using Geographical Information Systems: Example of Narman District (Erzurum) Turkey. Journal of Environmental Biology, 41(2), 293-301. https://doi.org/10.22438/jeb/41/2(SI)/JEB-03

Aliani, H., BabaieKafaky, S., Saffari, A., \& Monavari, S. M. (2017). Land evaluation for ecotourism development -an integrated approach based on FUZZY, WLC, and ANP methods. International Journal of Environmental Science and Technology, 14(9), 1999-2008. https://doi.org/10.1007/s13762-017-1291-5

Alsulaihi, I. A. (2017). Developing a rating system for sustainable office buildings using Simos' procedure. Journal of Engineering Research, 5(1), 59-88. https://kuwaitjournals.org/jer/ index.php/JER/article/view/1353

Arsić, S., Nikolić, D., \& Živković, Ž. (2017). Hybrid SWOT-ANPFANP model for prioritization strategies of sustainable development of ecotourism in National Park Djerdap, Serbia. Forest Policy and Economics, 80, 11-26.

https://doi.org/10.1016/j.forpol.2017.02.003

Asadpourian, Z., Rahimian, M., \& Gholamrezai, S. (2020). SWOT-AHP-TOWS analysis for sustainable ecotourism development in the Best Area in Lorestan Province, Iran. Social Indicators Research, 152(1), 289-315.

https://doi.org/10.1007/s11205-020-02438-0

Balaji, K., \& Senthil Kumar, V. (2018). Evaluation and selection of lean resourced employee in the manufacturing industries using the TOPSIS-Simos method. Proceedings of the Institution of Mechanical Engineers, Part B: Journal of Engineering Manufacture, 232(1), 162-171. https://doi.org/10.1177\%2F0954405416635069

Bali, A., Monovari, S. M., Riazi, B., Khorasani, N., \& Zarkesh, M. M. K. (2015). A spatial decision support system for ecotourism development in Caspian Hyrcanian mixed forests ecoregion. Boletim de Ciências Geodésicas, 21(2), 340-353. https://doi.org/10.1590/S1982-21702015000200001

Biglarfadafan, M., Danehkar, A., Pourebrahim, S., Shabani, A. A., \& Moeinaddini, M. (2016). Application of strategic fuzzy assessment for environmental planning; case of bird watch zoning in wetlands. Open Journal of Geology, 6(11), 13801400. https://doi.org/10.4236/ojg.2016.611099

Bunruamkaew, K., \& Murayam, Y. (2011). Site suitability evaluation for ecotourism using GIS \& AHP: A case study of Surat Thani province, Thailand. Procedia-Social and Behavioral Sciences, 21, 269-278.

https://doi.org/10.1016/j.sbspro.2011.07.024
Castellanos-Verdugo, M., Vega-Vázquez, M., Oviedo-García, M. Á., \& Orgaz-Agüera, F. (2016). The relevance of psychological factors in the ecotourist experience satisfaction through ecotourist site perceived value. Journal of Cleaner Production, 124, 226-235. https://doi.org/10.1016/j.jclepro.2016.02.126

Cini, F., Metastasio, R., Passafaro, P., Saayman, M., \& Merwe, P. v. d. (2017). Youth and ecotourism: A road trip towards the future sustainability of natural areas. In R. H. Price (Ed.), Ecotourism and sustainable tourism: Management, opportunities and challenges (pp. 1-28). Nova Science Publishers, Inc. https://www.researchgate.net/publication/314136604_Youth_ and_Ecotourism_A_Road_Trip_Towards_the_Future_Sustainability_of_Natural_Areas

Cobbinah, P. B. (2015). Contextualising the meaning of ecotourism. Tourism Management Perspectives, 16, 179-189. https://doi.org/10.1016/j.tmp.2015.07.015

D’Souza, C., Taghian, M., Marjoribanks, T., Sullivan-Mort, G., Manirujjaman, M., \& Singaraju, S. (2019). Sustainability for ecotourism: Work identity and role of community capacity building. Tourism Recreation Research, 44(4), 533-549. https://doi.org/10.1080/02508281.2019.1654727

Dangi, T. B., \& Gribb, W. J. (2018). Sustainable ecotourism management and visitor experiences: Managing conflicting perspectives in Rocky Mountain National Park, USA. Journal of Ecotourism, 17(3), 338-358.

https://doi.org/10.1080/14724049.2018.1502250

Dashti, S., Monavari, S. M., Hosseini, S. M., Riazi, B., \& Momeni, M. (2013). Application of GIS, AHP, Fuzzy and WLC in island ecotourism development (Case study of Qeshm Island, Iran). Life Science Journal, 10(1), 1274-1282.

http://www.lifesciencesite.com/lsj/life1001/194_13835li fe1001_1274_1282.pdf

de Sousa Pereira, L., \& Morais, D. C. (2020). Multicriteria decision model to establish maintenance priorities for wells in a groundwater system. Water Resources Management, 34(1), 377-392. https://doi.org/10.1007/s11269-019-02457-8

Dhami, I., Deng, J., Burns, R. C., \& Pierskalla, C. (2014). Identifying and mapping forest-based ecotourism areas in West Virginia-Incorporating visitors' preferences. Tourism Management, 42, 165-176.

https://doi.org/10.1016/j.tourman.2013.11.007

Du, X., \& Wang, Z. (2018). Optimizing monitoring locations using a combination of GIS and fuzzy multi criteria decision analysis, a case study from the Tomur World Natural Heritage site. Journal for Nature Conservation, 43, 67-74. https://doi.org/10.1016/j.jnc.2018.02.004

Figueira, J., \& Roy, B. (2002). Determining the weights of criteria in the ELECTRE type methods with a revised Simos' procedure. European Journal of Operational Research, 139(2), 317-326. https://doi.org/10.1016/S0377-2217(01)00370-8

Fontana, M. E., Morais, D. C., \& de Almeida, A. T. (2011). A MCDM model for urban water conservation strategies adapting simos procedure for evaluating alternatives intra-criteria. In R. H. C. Takahashi, K. Deb, E. F. Wanner, \& S. Greco (Eds.), Lecture notes in computer science: Vol. 6576. Evolutionary multicriterion optimization (pp. 564-578). Springer.

Food and Agriculture Organization. (1976). A framework for land evaluation. FAO Soil Bulletin, No 32. http://www.fao. org/3/x5310e/x5310e04.htm\#chapter\%203:\%20land\%20suitability\%20classifications

Fung, T., \& Wong, F.-K. (2007). Ecotourism planning using multiple criteria evaluation with GIS. Geocarto International, 22(2), 87-105. https://doi.org/10.1080/10106040701207332 
Ghamgosar, M., Haghyghy, M., Mehrdoust, F., \& Arshad, N. (2011). Multicriteria decision making based on analytical hierarchy process (AHP) in GIS for tourism. Middle-East Journal of Scientific Research, 10(4), 501-507.

https://www.idosi.org/mejsr/mejsr10(4)11/14.pdf

Gigović, L., Pamučar, D., Lukić, D., \& Marković, S. (2016). GISFuzzy DEMATEL MCDA model for the evaluation of the sites for ecotourism development: A case study of "Dunavski ključ" region, Serbia. Land Use Policy, 58, 348-365. https://doi.org/10.1016/j.landusepol.2016.07.030

Górecka, D. (2016). Using Sipres - A Fusion of the revised Simos' procedure and Zapros - in the road route selection process. Optimum. Economic Studies, 83(5), 97-112.

https://www.ceeol.com/search/article-detail?id=665486

Gourabi, B. R., \& Rad, T. G. (2013). The analysis of ecotourism potential in Boujagh wetland with AHP method. Life Science Journal, 10(2s), 251-258. http://www.lifesciencesite.com/lsj/li fe1002s/044_15083life1002s_251_258.pdf

Govindan, K., Kadziński, M., \& Sivakumar, R. (2017). Application of a novel PROMETHEE-based method for construction of a group compromise ranking to prioritization of green suppliers in food supply chain. Omega, 71, 129-145. https://doi.org/10.1016/j.omega.2016.10.004

Hidrawati, H., Normayasari, N., Sahari, S., Fyka, S. A., \& Yusria, W. O. (2020). A study of the potential of ecotourism development in Konawe Islands Regency, Southeast Sulawesi Province, Indonesia. HABITAT, 31(3), 115-124.

https://doi.org/10.21776/ub.habitat.2020.031.3.14

Hunt, C. A., Durham, W. H., Driscoll, L., \& Honey, M. (2015). Can ecotourism deliver real economic, social, and environmental benefits? A study of the Osa Peninsula, Costa Rica. Journal of Sustainable Tourism, 23(3), 339-357. https://doi.org/10.1080/09669582.2014.965176

Jamaliah, M. M., \& Powell, R. B. (2018). Ecotourism resilience to climate change in Dana Biosphere Reserve, Jordan. Journal of Sustainable Tourism, 26(4), 519-536. https://doi.org/10.1080/09669582.2017.1360893

Jeong, J. S., García-Moruno, L., Hernández-Blanco, J., \& JaraízCabanillas, F. J. (2014). An operational method to supporting siting decisions for sustainable rural second home planning in ecotourism sites. Land Use Policy, 41, 550-560. https://doi.org/10.1016/j.landusepol.2014.04.012

Jeong, J. S., \& Ramírez-Gómez, Á. (2018). Development of a web graphic model with fuzzy-decision-making Trial and Evaluation Laboratory/Multi-criteria-Spatial Decision Support System (F-DEMATEL/MC-SDSS) for sustainable planning and construction of rural housings. Journal of Cleaner Production, 199, 584-592. https://doi.org/10.1016/j.jclepro.2018.07.227

Jhariya, D., Kumar, T., Gobinath, M., Diwan, P., \& Kishore, N. (2016). Assessment of groundwater potential zone using remote sensing, GIS and multi criteria decision analysis techniques. Journal of the Geological Society of India, 88(4), 481-492. https://doi.org/10.1007/s12594-016-0511-9

Jozi, S., \& Majd, N. M. (2015). Ecological land capability evaluation of Dehloran county in order to ecotourism development. Journal of the Indian Society of Remote Sensing, 43(3), 571-581. https://doi.org/10.1007/s12524-014-0427-z

Kahneman, D. (2021). Shortcomings of the AHP method. In Management for Professionals. N. Munier \& E. Hontoria (Eds.), Uses and limitations of the AHP method (pp. 41-90). Springer. https://doi.org/10.1007/978-3-030-60392-2_5

Kaptan Ayhan, Ç., Cengiz Taşlı, T., Özkök, F., \& Tatlı, H. (2020). Land use suitability analysis of rural tourism activities: Yenice, Turkey. Tourism Management, 76, 1-11. https://doi.org/10.1016/j.tourman.2019.07.003
Karthikeyan, R., Venkatesan, K. G. S., \& Chandrasekar, A. (2016). A comparison of strengths and weaknesses for analytical hierarchy process. Journal of Chemical and Pharmaceutical Sciences, 9(3), 12-15. https://www.jchps.com/issues/ Volume\%209_Issue\%203/CSE\%2042.pdf

Kiper, T., Uzun, O., \& Üstün Topal, T. (2018). Rural development oriented ecotourism planning on Catchment Basin Scale: The case of Pabuçdere and Kazandere Catchment Basin. Journal of Agricultural Science and Technology, 19, 293-305. https://jast.modares.ac.ir/article-23-454-en.pdf

Lonn, P., Mizoue, N., Ota, T., Kajisa, T., \& Yoshida, S. (2018). Evaluating the contribution of community-based ecotourism (CBET) to household income and livelihood changes: A case study of the Chambok CBET program in Cambodia. Ecological Economics, 151, 62-69. https://doi.org/10.1016/j.ecolecon.2018.04.036

Mahdavi, A., \& Niknejad, M. (2014). Site suitability evaluation for ecotourism using MCDM methods and GIS: Case studyLorestan province, Iran. Journal of Biodiversity and Environmental Sciences, 4(6), 425-437.

http://citeseerx.ist.psu.edu/viewdoc/download?doi=10.1.1.65 $1.9497 \&$ rep $=$ rep $1 \&$ type $=$ pdf

Mahdavi, A., Niknejad, M., \& Karami, O. (2015). A fuzzy multicriteria decision method for ecotourism development locating. Caspian Journal of Environmental Sciences, 13(3), 221-236. https://cjes.guilan.ac.ir/?_action=articleInfo\&article=1373

Malczewski, J. (1999). GIS and multicriteria decision analysis. John Wiley \& Sons, Inc. https://www.wiley.com/en-us/GIS+a nd+Multicriteria+Decision+Analysis-p-9780471329442

Marzouk, M., Nouh, A., \& El-Said, M. (2014). Developing green bridge rating system using Simos' procedure. HBRC Journal, 10(2), 176-182. https://doi.org/10.1016/j.hbrcj.2013.10.001

Merad, M., Dechy, N., Serir, L., Grabisch, M., \& Marcel, F. (2013). Using a multi-criteria decision aid methodology to implement sustainable development principles within an organization. European Journal of Operational Research, 224(3), 603-613. https://doi.org/10.1016/j.ejor.2012.08.019

Mondino, E., \& Beery, T. (2019). Ecotourism as a learning tool for sustainable development. The case of Monviso Transboundary Biosphere Reserve, Italy. Journal of Ecotourism, 18(2), 107-121. https://doi.org/10.1080/14724049.2018.1462371

Nahuelhual, L., Carmona, A., Lozada, P., Jaramillo, A., \& Aguayo, M. (2013). Mapping recreation and ecotourism as a cultural ecosystem service: An application at the local level in Southern Chile. Applied Geography, 40, 71-82. https://doi.org/10.1016/j.apgeog.2012.12.004

Nino, K., Mamo, Y., Mengesha, G., \& Kibret, K. S. (2017). GIS based ecotourism potential assessment in Munessa Shashemene Concession Forest and its surrounding area, Ethiopia. Applied Geography, 82, 48-58. https://doi.org/10.1016/j.apgeog.2017.02.010

Olafsdottir, G. (2013). On nature-based tourism. Tourist Studies, 13(2), 127-138. https://doi.org/10.1177/1468797613490370

Papathanasiou, J. (2021). An example on the use and limitations of MCDA: The case of fuzzy VIKOR. Examples and Counterexamples, $1,100001$. https://doi.org/10.1016/j.exco.2020.100001

Ribas, J. R., \& da Silva Rocha, M. (2015). A decision support system for prioritizing investments in an energy efficiency program in Favelas in the city of Rio de Janeiro. Journal of Multi-Criteria Decision Analysis, 22(1-2), 89-99. https://doi.org/10.1002/mcda.1524

Ronizi, S. R. A., Mokarram, M., \& Negahban, S. (2020). Utilizing multi-criteria decision to determine the best location for 
the ecotourism in the east and central of Fars province, Iran. Land Use Policy, 99, 105095.

https://doi.org/10.1016/j.landusepol.2020.105095

Sahani, N. (2019). Application of analytical hierarchy process and GIS for ecotourism potentiality mapping in Kullu District, Himachal Pradesh, India. Environment, Development and Sustainability, 22, 6187-6211. https://doi.org/10.1007/s10668-019-00470-w

Shanian, A., Milani, A., Carson, C., \& Abeyaratne, R. (2008). A new application of ELECTRE III and revised Simos' procedure for group material selection under weighting uncertainty. Knowledge-Based Systems, 21(7), 709-720. https://doi.org/10.1016/j.knosys.2008.03.028

Siskos, E., \& Tsotsolas, N. (2015). Elicitation of criteria importance weights through the Simos method: A robustness concern. European Journal of Operational Research, 246(2), 543-553. https://doi.org/10.1016/j.ejor.2015.04.037

Sriarkarin, S., \& Lee, C.-H. (2018). Integrating multiple attributes for sustainable development in a national park. Tourism Management Perspectives, 28, 113-125. https://doi.org/10.1016/j.tmp.2018.08.007

Strickland-Munro, J., \& Moore, S. (2013). Indigenous involvement and benefits from tourism in protected areas: A study of Purnululu National Park and Warmun Community, Australia. Journal of Sustainable Tourism, 21(1), 26-41. https://doi.org/10.1080/09669582.2012.680466

Şakar, D., Aydin, A., \& Akay, A. E. (2020). Using GIS-based multicriteria decision support system for planning road networks with visual quality constraints: A case study of protected areas in Ankara, Turkey. Environmental Monitoring and Assessment, 192(7), 1-13. https://doi.org/10.1007/s10661-020-08417-9

The International Ecotourism Society. (2019). The definition. https://ecotourism.org/what-is-ecotourism/
Tseng, M.-L., Lin, C., Lin, C.-W. R., Wu, K.-J., \& Sriphon, T. (2019). Ecotourism development in Thailand: Community participation leads to the value of attractions using linguistic preferences. Journal of Cleaner Production, 231, 1319-1329. https://doi.org/10.1016/j.jclepro.2019.05.305

Ullah, K. M., \& Hafiz, R. (2014). Finding suitable locations for ecotourism development in Cox's Bazar using Geographical Information System and Analytical Hierarchy process. Geocarto International, 29(3), 256-267. https://doi.org/10.1080/10106049.2012.760005

Wishitemi, B. E. L., Momanyi, S. O., Ombati, B. G., \& Okello, M. M. (2015). The link between poverty, environment and ecotourism development in areas adjacent to Maasai Mara and Amboseli protected areas, Kenya. Tourism Management Perspectives, 16, 306-317. https://doi.org/10.1016/j.tmp.2015.07.003

Wondirad, A., Tolkach, D., \& King, B. (2020). Stakeholder collaboration as a major factor for sustainable ecotourism development in developing countries. Tourism Management, 78, 104024. https://doi.org/10.1016/j.tourman.2019.104024

Yang, X., Zhao, Z., \& Lu, S. (2016). Exploring spatial-temporal patterns of urban human mobility hotspots. Sustainability, 8(7), 674. https://doi.org/10.3390/su8070674

Zabihi, H., Alizadeh, M., Wolf, I. D., Karami, M., Ahmad, A., \& Salamian, H. (2020). A GIS-based fuzzy-analytic hierarchy process (F-AHP) for ecotourism suitability decision making: A case study of Babol in Iran. Tourism Management Perspectives, 36, 100726. https://doi.org/10.1016/j.tmp.2020.100726

Zarghi, A. H., Bidkhori, A., \& Hosseini, S. M. (2019). Site suitability evaluation for ecotourism using GIS \& MCDM: A case study of Bazangan Lake Watershed, Iran. Journal of Novel Applied Sciences, 8(8), 170-181. http://jnasci.org/wp-content/uploads/2019/12/JNASCI-2019-170-181.pdf 